\title{
PIIISGUC.ORG
}

"iş, GÜÇ" ENDÜSTRI iLişKILERI VE INSAN KAYNAKLARI DERGISi

"IS, GUC" INDUSTRIAL RELATIONS AND HUMAN RESOURCES JOURNAL

\section{Çalışanlarda Psikolojik Yıldırma ve Endişe Düzeyi}

\author{
Gamze Ebru ÇíFTÇi \\ Bilim Uzmanı, Kırıkkale Üniversitesi \\ Yard.Doç.Dr.Melahat ÖNEREN \\ Kırıkkale Üniversitesi, İşletme Anabilim Dalı, Öğretim Üyesi. \\ Psikolog Ayşe ÖNEM \\ Psikolog, Kırıkkale Üniversitesi, Psikolojik Danışma Birimi
}

Nisan/April 2013, Cilt/Vol: 15, Say1/Num: 2, Page: 63-81

ISSN: 1303-2860, DOI: 10.4026/1303-2860.2013.0226.x

Makalenin on-line kopyasına erişmek için / To reach the on-line copy of article:

http://www.isguc.org/index.php?p=article\&id=511\&cilt=15\&sayi=2\&yil=2013

Makale İçin İletişim/Correspondence to:

Gamze Ebru Çiftçi/email: gamzeebruciftci@hotmail.com 


\title{
FIIISGUCOPG 0200020213 \\ "İş,Güç" Endüstri ilişkileri ve İnsan Kaynakları Dergisi "Işs,Güç" Industrial Relations and Human Resources Journal
}

\author{
Nisan/April 2013, Cilt/Vol: 15, Say1/Num: 2, \\ Sayfa/Page: 63-81, DOI: 10.4026/1303-2860.2013.0226.x
}

"Işs,Güç" Endüstri İlişkileri ve İnsan Kaynakları Dergisi, yılda dört kez yayınlanan hakemli, bilimsel elektronik dergidir. Çalışma hayatına ilişkin makalelere yer verilen derginin temel amacl; belirlenen alanda akademik gelişime ve paylaşıma katkıda bulunmaktır.

"İ̧s,Güç" Endüstri İlişkileri ve İnsan Kaynakları Dergisi'nde, 'Türkçe' ve 'İngilizce' olarak iki dilde makale yayınlanmaktadır. "İş,Güç" Endüstri İlişkileri ve İnsan Kaynakları Dergisi, ulusal ve uluslararası birçok indekste taranmaktadır. (Cabell's Directories, Ebsco Socindex, Index Islamicus, Index Copernicus International, Worldwide Political Science Abstracts, Sociological Abstract, Ulakbim Sosyal Bilimler Veritaban,, ASOS Index)

Editör / Editor in Chief

Aşkın Keser (Uludağ University)

\section{Editör Yardımcıları / Co-Editors}

Şenol Baştürk (Uludăg University)

K.Ahmet Sevimli (Uludağ University)

Gözde Yllmaz (Marmara University)

\section{Uygulama / Design}

Yusuf Budak (Kocaeli University)

Tarandiğı Indeksler / Indexes ASOS INDEX

CABELL'S DIRECTORIES

EBSCO SOCINDEX

Index ISLAMICUS

Index COPERNICUS Int.

Sociological Abstract

ULAKBİM Sosyal Bilimler

Veritanı

Worldwide Political Science

Abstracts

\author{
Yayın Kurulu / Editorial Board \\ Dr.Şenol Baştürk (Uludă̆ University) \\ Yrd.Doç.Dr.Zerrin Fırat (Uludă̆ University) \\ Doç.Dr.Aşkın Keser (Uludă̆ University) \\ Prof.Dr.Ahmet Selamoğlu (Kocaeli University) \\ Yrd.Doç.Dr.Ahmet Sevimli (Uludağ University) \\ Doç.Dr.Abdulkadir Şenkal (Kocaeli University) \\ Doç.Dr.Gözde Yılmaz (Marmara University) \\ Yrd.Doç.Dr.Memet Zencirkıran (Uludă̆ University)
}

Uluslararası Danışma Kurulu / International Advisory Board

Prof.Dr.Ronald Burke (York University - Kanada)

Assoc.Prof.Dr.Glenn Dawes (James Cook University - Avustralya)

Prof.Dr.Jan Dul (Erasmus University - Hollanda)

Prof.Dr.Alev Efendioğlu (University of San Francisco - ABD)

Prof.Dr.Adrian Furnham (University College London - Ingiltere)

Prof.Dr.Alan Geare (University of Otago - Yeni Zellanda)

Assoc. Prof. Dr. Diana Lipinskiene (Kaunos University - Litvanya)

Prof.Dr.George Manning (Northern Kentucky University - ABD)

Prof.Dr.Mustafa Özbilgin (Brunel University - UK)

Assoc. Prof. Owen Stanley (James Cook University - Avustralya)

Prof.Dr.Işık Urla Zeytinoğlu (McMaster University - Kanada)

Ulusal Danışma Kurulu / National Advisory Board

Prof.Dr.Yusuf Alper (Uludağ University)

Prof.Dr.Veysel Bozkurt (İstanbul University)

Prof.Dr.Toker Dereli (Işık University)

Prof.Dr.Nihat Erdoğmuş (İstanbul Şehir University)

Prof.Dr.Ahmet Makal (Ankara University)

Prof.Dr.Süleyman Özdemir (İstanbul University)

Prof.Dr.Ahmet Selamoğlu (Kocaeli University)

Prof.Dr.Nadir Suğur (Anadolu University)

Prof.Dr.Nursel Telman (Maltepe University)

Prof.Dr.Cavide Uyargil (İstanbul University)

Prof.Dr.Engin Yıldırım (Anayasa Mahkemesi)

Doç.Dr.Arzu Wasti (Sabancı University)

Dergide yayınlanan yazllardaki görüşler ve bu konudaki sorumluluk yazarlarına aittir.

Yayınlanan eserlerde yer alan tüm içerik kaynak gösterilmeden kullanılamaz.

All the opinions written in articles are under responsibilities of the authors.

The published contents in the articles cannot be used without being cited. 


\title{
Çalışanlarda Psikolojik Yıldırma ve Endişe Düzeyi
}

\author{
Gamze Ebru ÇíTÇi \\ Bilim Uzmanı, Kırıkkale Üniversitesi \\ Yard.Doç.Dr.Melahat ÖNEREN \\ Kırıkkale Üniversitesi, İşletme Anabilim Dalı, Öğretim Üyesi. \\ Psikolog Ayşe ÖNEM \\ Psikolog, Kırıkkale Üniversitesi, Psikolojik Danışma Birimi
}

\begin{abstract}
Today, there is an increase in the number of employees exposed to mobbing. Therefore, there is more research on the topic and most of the research reveals that mobbing has a negative effect on the careers of employees. This study focuses on the effect of mobbing on the levels of anxiety among employees. In this context, a survey was conducted to 107 employees working in an office of a district municipality. The obtained data was studied through ANOVA, t-test, frequency, correlation and regression analyses in SPSS 16.0. The results show that there is a significant relationship between mobbing and anxiety levels among the employees.
\end{abstract}

Keywords: $\quad$ Mobbing, psychological intimidation, worry, anxiety, employees

\section{Özet}

Günümüzde psikolojik yıldırma davranışına maruz kalan çalışan sayısı gittikçe artmaktadır. Bu artışla birlikte konuya ilişkin araştırmalar hız kazanmakta ve araştırmalarda psikolojik yıldırmanın çalışanların iş yaşamını olumsuz etkilediği sonucuna ulaşılmaktadır. Bu çalışmada ise, psikolojik yıldırma davranışlarının çalışanların endişe(anksiyete) durumuna etki düzeyi ölçülmeye çalışllmıştır. Bu bağlamda bir Büyükşehir Belediyesine bağll ilçe belediyede görevli 107 çalışana anket form uygulanmıştır. Elde edilen verilere, SPSS 16. programında, frekans, ANOVA, $t$-Testi, korelasyon ve regrasyon analizleri yapılmıştır. Analizler sonucunda, psikolojik yıldırma davranışları ile çalışanların endişe(anksiyete) durumları arasında anlamlı bir ilişki saptanmıştır. 
"iş, GÜç" Endüstri İlişkileri ve İnsan Kaynakları Dergisi

"IS, GUC" Industrial Relations and Human Resources Journal
Nisan/April 2013 - Cilt/Vol: 15 - Sayı/Num: 02

Sayfa/Page:63-81, DOI: 10.4026/1303-2860.2013.0226.x

\section{Giriş}

İş ve iş yaşamı insan hayatının büyük bir bölümünü oluşturur. İş yaşamında birey birçok kişi ile beraber çalışmakta olup, örgüt ve/veya toplum bazında farklı olumlu veya olumsuz davranışlara maruz kalmaktadır. İş yaşamında özellikle son yillarda iş gören üzerindeki etkileri daha çok önemsenen psikolojik yıldırma (mobbing) iş hayatında çalışanlara sıkıntı veren olumsuz bir davranış biçimi olarak karşımıza çıkmaktadır. $\mathrm{Bu}$ olumsuz davranışlar, küreselleşmenin artması, teknolojinin hızla gelişmesi, işletmeler arası rekabetin hiz kazanmasına paralel olarak artmış ve iş dünyasının çözüme ihtiyaç duyan büyük sorunu olarak yerini almıştır. Çünkü, iş yaşamında sahip olunan en büyük kaynak insan kaynağıdır ve yöneticinin en önemli görevi bu kaynağın etkin ve verimli bir şekilde istihdam edilebilmesini sağlamaktır. Psikolojik yıldırma ise bu beşeri kaynağı tüketen önemli bir etkendir.

Psikolojik yıldırma, iş yaşamında olumsuz yansımaları yanında bireylerin sağlığında yarattığı durumlar oldukça vahimdir. Bu araştırmada, psikolojik yıldırmanın çalışanların endişe (anksiyete) durumlarına etkisi incelenmeye çalışılacaktır. $\mathrm{Bu}$ amaçlar doğrultusunda,

1. Psikolojik yıldırma davranışları ile çalışanların endişe durumları arasında anlamlı bir ilişki var mıdır? Bu yıldırma davranışları endişenin ne kadarını açıklamaktadır,

2. Psikolojik yıldırma davranışları ile çalışanların fiziksel, bilişsel, davranışsal ve duygusal endişe durumları arasında anlamlı bir ilişki var mıdır? Bu yıldırma davranışları fiziksel, bilişsel, davranışsal ve duygusal endişe durumlarının ne kadarını açıklamaktadır,

3. Çalışanların demografik özellikleri ile endişe durumları arasında anlamlı bir ilişki var mıdır? Sorularına yanıt aranacaktır.

Bu amaçla yola çıkılan bu araştırma üç bölümden oluşturulmuştur. Birinci bölümde psikolojik yıldırma davranışlarının ve endişe tanımı, kapsamı açıklanacak, nedenleri ile yıldırma davranışlarının boyutları ile çalışan üzerindeki etkileri incelenmeye çalışacaktır. Çalışmanın ikinci bölümde istatistiki bulgular, üçüncü bölümde ise sonuç ve tartışma bulunmaktadır.

\section{Psikolojik Yıldırmanın Tanımı ve Kapsamı}

Psikolojik yıldırma, ulusal ve uluslararası yazında çeşitli şekillerde tanımlanabilmektedir. Bu tanımlar, psikolojik şiddet, psikolojik taciz, mobbing, iş yerinde zorbalık, psikolojik terör şeklindedir.

Kavramsal olarak mobbing", ingilizce bir kelime olup, asıl olarak "mob" kökünden gelmektedir. "Mob" sözcüğü aşırı şiddetle ilişkili ve yasaya uygun olmayan kalabalığ ifade etmektedir. Sözcük, Latince "mobile vulgus" dan türemiştir. "Mobbing" sözlükte, çevresini kuşatma, topluca saldırma ya da sıkıntı verme anlamındadır (Yücetürk, 2005:243). Mobbing kavramı "güruh halinde saldırmak, kitle halinde hücum etmek, merakla etrafını sarmak, yığılmak anlamları ile birlikte insan kalabalığı, izdiham, ayaktakımı, avam ve konuşma dilinde de gansterler çetesi" olarak da tanımlanmıştır (Avery vd., 1999: 629).

Mobbing, ilk olarak Avusturyalı bir etoloji uzmanı olan Konrad Lorenz tarafindan, küçük hayvan gruplarının, tehdit olarak gördükleri büyük bir tek hayvanı korkutmak için yaptıkları, bir hayvan grup davranışı olarak tanımlanmıştır. Daha sonra, İsveçli endüstri psikoloğu Peter Paul Heinemann, çocukların sınıf içindeki davranışlarını incelerken, bir grup çocuğun, tek bir çocuğa yönelik tahrip edici davranışını tanımlarken, bu kavramı Lorenz'den ödünç almıştır (Leymann, 1996:4). Yıldırma kavramını ilk defa çalışma ortamlarında ortaya çıkan ve engel olunması gereken bir olgu olarak ele alan, inceleyen ve tanımlayan kişi ise Heinz Leymann olmuştur.

Leymann (1996:168) psikolojik yıldırmayı; bir veya birkaç kişinin bir kişiye yönelik olarak sergilediği organize ve 
süreklilik arz eden nitelikte, fiziksel ve/veya psikolojik zarara yol açan, çok sık ve uzun bir dönem boyunca (aylarca veya yıllarca) süren tacizci davranışlar-saldırganlık olarak tanımlanmıştır. Leymann bu tanımı ile psikolojik yıldırmanın sistematik bir şekilde gerçekleştiğini ve süreklilik arz eden bir durum olduğunu vurgulamıştır. Leymann'dan sonra psikolojik yıldırmanın tanımı birçok araştırmacı tarafından yapılmaya başlanmıştır. Örneğin, Davenport ve arkadaşlarına (2003:15) göre psikolojik yıldırma; bir kişinin diğer insanları kendi rızaları ile veya rızaları dışında başka bir kişiye karşı etrafında toplaması ve sürekli kötü niyetli hareketlerde bulunma, ima, alay ve karşısındakinin toplumsal itibarını düşürme gibi yollarla, saldırgan bir ortam yaratarak, söz konusu kişiyi işten çıkarmaya zorlayan duygusal saldırıdır. Tınaz (2006:7) psikolojik yıldırmayı, psikolojik taciz olarak telafuz etmiş ve yıldırmayı; kuşatma, taciz ve rahatsız etme veya sıkıntı verme olarak ifade etmektedir.

Einarsen (2000), İskandinav ülkelerinde psikolojik yıldırma kavramının, bir yönetici, şef veya çalışanın sistematik ve devamlı olarak iş arkadaşları, astları ve üstleri tarafından kurbanlaştırıldığı, kötü davranışlara maruz bırakıldığı tüm durumları tarif etmekte genel olarak kullanıldığını belirtmektedir. Yıldırma davranışları genel olarak iş ile ilgili konularda gerçekleşirken bazı zamanlarda çalışanların özel hayatlarına müdahale şeklinde de gerçekleşebilir (Beswick, 2006: 12). Yildırma durumunda saldırgan yaş, din, ırk, cinsiyet gibi konularda ayrımcılık yapabilir; bunun da ötesinde, kişiyi iş yaşamından dışlamak amacıyla psikolojik taciz, kötü davranış, uygun olmayan görev ve adaletsiz maaş yöntemiyle yıldırmak isteyebilir (Çobanoglu, 2005:23).

Genel olarak baktığımızda psikolojik yıldırma "içinde birçok çeşitte psikolojik şiddeti barındıran, bireyin iş ve sosyal hayatını olumsuz etkileyen, baskı, taciz, sıkıntı, stres ve yıldırma durumlarını kapsayan iş yaşamında ki uygulaması kasıtlı planlanan, sık tekrarlanan ve süreklilik arz eden olumsuz davranışlar bütünüdür diyebiliriz. Psikolojik yıldırma davranışına uğrayan kişi aşırı stres altındandır ve kendine olan özgüvenini kaybetmiş durumdadır. Bu yüzden kişi kendini yalnızlığa ve büyük bir bunalıma doğru iter. Bu kişi zaman geçtikçe hem iş hayatında, hem de sosyal hayatta ki etkinliğini kaybetme derecesine gelmektedir.

Psikolojik yıldırma davranışlarının çeşitli şekillerde gerçekleşmesi olasıdır. Örneğin, psikolojik yıldırma davranışının mağdur üzerinde fizyolojik ve psikolojik şekli ile gerçekleşmesi mümkündür. Fakat psikolojik yıldırmayı fiziksel yıldırmadan ayıran en önemli özellik mağdur üzerindeki belirtilerinin uzun süre sonra fark edilebilir olmasıdır. Bu nedenle, mağdur için psikolojik yıldırmanın ilk aşamada teşhis ve ıspatında zorluklar yaşanmaktadır.

Leymann, psikolojik yıldırma davranışlarını, mağdurun etkilenmesi bakımından beş kategori şeklinde sınıflandırmıştır (Leymann, 1996,170-173):

1.Iletişime yönelik saldırılar: Kişinin çevresiyle iletişimini sınırlamaya yönelik davranışlar, sürekli sözünün kesilmesi, yüksek sesle azarlanması, karar süreçlerinin dışında tutulması, sözel saldırı ve tehdit alması.

2.Sosyal ilişkilere yönelik saldırılar: İş arkadaşların veya amirlerinin mağdurla konuşmaması, yokmuş gibi davranmaları, odasının diğerlerinden izole bir yere taşınmasıdır.

3.Kişisel imajına yönelik saldırılar: Mağdurun hakkında söylentiler yayılması, bir özrüyle alay edilmesi, konuşmasıyla, yürüyüşüyle, etnik kökeniyle ilgili alaycı espriler yapılması, isim takılmasıdır.

4.Mesleki kariyerine yönelik saldırılar: Mağdura ya hiç iş verilmemesi ya da kapasitesinin altında veya çok anlamsız işlerin verilmesidir.

5.Să̆lı̆̆ına yönelik saldırılar: Mağdurun, tehlikeli, ağır ve zor işler yapmaya zorlanması, şiddet hatta doğrudan cinsel taciz uygulanmasıdır. 


\section{2. İş Yaşamında Psikolojik Yıldırma Davranışının Nedenleri}

İş yaşamında psikolojik yıldırma davranışlarının çok çeşitli nedenleri olabilmektedir. Bu nedenler, bireysel olabileceği gibi örgütsel düzeyde de olabilir. Yapılan birçok araştırma psikolojik yıldırma davranışlarının farklı nedenler ve çeşitli olgular üzerinde gerçekleşebildiğini göstermektedir. Örneğin; Zapf (1999)'a göre iş yerindeki psikolojik yıldırmanın nedenleri tek yönlü teorilerle açiklamak mümkün değildir. Mağdurun ve saldırganın kişilik özelliklerinin yanı sıra, sosyal ve organizasyonel sebepler oldukça önemlidir. White (2004) ise psikolojik yıldırmanın kaynağını anlayabilmek için psikodinamik bakış açısını kullanmayı önermiştir. Bu yaklaşım sistematik bakış açısına benzer şekilde bireyin, kişilerarası ilişkilerin, grubun ve organizasyonun bilinç dişı süreçlerinin yıldırmada hep birlikte rol oynadığını iddia eder. Yıldırmayı besleyen organizasyonel faktörler (kültür, değerler, yapı, süreç ve değişim faktörleri), grup dinamikleri, mağdur ve mağduru inciten olaylar hep birlikte ele alınmalıdır.

Björkqvist ve arkadaşlarına (1994:31) göre psikolojik yıldırmanın üç temel nedeni vardır. $\mathrm{Bu}$ nedenler, kişilerin işyerindeki statülerini ve iş pozisyonlarını, kıskançlığı ve saldırganların kendilerine olan güvensizliğidir.

Barutçugil (2004), iş yerinde oluşabilecek olumsuz durumların nedeninin gücün yanlış kullanımından kaynaklandığını dile getirmiştir. Başka insanların inançlarını, duygularını ve davranışlarını etkileme yeteneği olarak "güç" her organizasyonda bütün eylemleri ve ilişkileri bir şekilde etkilemektedir. Bir kişinin ya da bir grubun hedef seçilmiş kişiye karşı uyguladıkları devamlı, tekrarlanan, alçaltıcl, küçük görücü, yıldırıcı, haksız söz ve davranışları ifade edecek şekilde gücün kötüye kullanılması sonucunda psikolojik yıldırma davranışları meydana gelebilir. Özellikle yöneticilerin bu durumda yaklaşımları psikolojik yıldırma davranışlarının temellerini oluşturabilmektedir. Bazı işletmelerde, yönetim, bu tür saldırıların yapılabileceği ortamlara göz yumabilmekte ve hatta destek olacak şekilde yaklaşımlar gösterebilmektedir. Eğer bir örgüt içerisinde bu tür saldırıları önlemeye, gözlemlemeye veya cezalandırmaya yönelik politikalar mevcut değilse, saldırganlar şiddet yaratmaya devam edecektir ve örgüt de sonuçlarına katlanmak zorunda kalacaktır (Voroney, 2005: 23).

Tiyek'in (2011), yıldırma ve yönetim becerileri üzerine yaptığı bir araştırmada yıldırmaya uğrama ile yönetim becerileri arasındaki ilişkiyi tespit etmiştir. Tiyek, araştırmanın sonucunda yöneticilerin yönetim becerilerinin geliştirilmesi yıldırma davranışlarının yaşanmaması açısından önemli olduğunu ve yıldırma davranışlarının yaşanmaması için yapılması gereken en önemli uygulamalardan bir tanesini yönetici pozisyonunda çalışacak kişilerin doğru bir şekilde tespit edilmesi ve kişilerin yönetici olduktan sonra yönetim becerilerini geliştirici çalışmaların devam etmesini sağlayıcı düzenlemelerin yapılması oluşturduğunu belirtmiştir.

$\mathrm{Bu}$ nedenle psikolojik yıldırma davranışı uygulayan kişilerin, özellikle de yöneticilerin kişilik özellikleri onları psikolojik yıldırma davranışını uygulamaya itmektedir. İrlanda'da kurbanlar üzerinde yapılan bir araştırma sonucunda, kurbanların \%75'i, kendilerine psikolojik yıldırma uygulayan kişilerin kendilerini kıskandıkları için bu tür davranışlar sergilediklerini belirtmişlerdir (Seigne,1998:2).

Psikolojik yıldırmanın nedeni yıldırma davranışını uygulayan kişinin kişilik özelliklerinin olması yanında, örgüt yapılarından da kaynaklı olabilmektedir. Örgütte çalışanlar arasındaki rollerin belirsiz olması, beceriden yoksun bir yönetim, örgütte var olan adaletsizlik, hiyerarşik yapıdaki düzensizlik, örgütte etik kuralların olmaması, psikolojik yıldırma davranışı uygulayan kişiler üzerinde denetim mekanizmasının çalışmıyor olması gibi nedenlerde iş yaşamında psikolojik yıldırma davranışlarının oluşumuna kaynak oluşturabilir. Hiyerarşik yapının sertliği/esnekliği, yönetimin demokrat olup olmaması, şikâyetlerin adilce değerlendirilip değerlendirilmemesi gibi faktörler yıldırma 
davranışlarının ortaya çıkması ve varlığını sürdürebilmesi açısından önem teşkil etmektedir (Tayyar, 2008: 16).

Psikolojik yıldırma sorununa makro boyutta bakıldığında, işsizliğin yükseldiği ve işten çıkarmaların giderek çoğaldığı ekonomik kriz dönemlerinde, psikolojik taciz uygulamalarının bilinçli bir şekilde arttığı ve işçinin sözleşmesini feshetme yolunda baskıların yoğunlaştığı göze çarpmaktadır. Bunun yanı sıra 1990'larda ağırlık kazanmaya başlayan kamudaki yeniden yapılanma çalışmaları (küçülme, etkinlik, verimlilik, taleplerdeki artış, artan stres oranı, iş güvencesinin olmaması gibi) da psikolojik tacizi arttırıcı bir faktördür(Yıldız ve Kılkış,2010:76).

Psikolojik yıldırma davranışlarının nedenlerinin, mağdur bireyin bazı özelliklerinden kaynaklı olabilmesi de mümkündür. Örneğin, Huber (1998:24-25), işyerlerinde dört farklı özellikteki kişilerin mobbing kurbanı olma tehlikesiyle karşı karşıya olduklarını belirtmiştir. Bu özellikte olan kişiler; diğer insanlardan uzak olan yalnız kişiler, sıra dışı kişiler, başarılı bir kişiler veya işe yeni başlayan kişilerdir. Özellikle yaratıcı bireyler, yeni fikirler geliştirdiği için yıldırılmaya daha fazla hedef olmaktadır. Bu tür kişiler, daha yüksek pozisyonu olan personele tehdit oluşturacağı endişesi ile hedef seçilmektedir. Bazı araştırmacılar psikolojik yıldırmaya hedef olan kişilerin, sosyal ortamlarda genellikle endişeli ve kendine daha az saygı duyan kişiler olduğunu öne sürülmektedirler. Araştırmacılara göre bu kişiler dürüst ve oldukça tecrübesizdirler. Her zaman mahcup, hoşgörülü, iyi niyetli ve özür dilemeye hazır bir tavır içindedirler. Bu özelliklerin de saldırganları, psikolojik yıldırma eylemi için cesaretlendireceği açıktır (Yücetürk,2006:5).

Aslında psikolojik yıldırma, tek bir nedene bağlanamayacak kadar karmaşık bir konu olduğunu söylemek mümkündür. Saldırıda bulunan kişinin psikolojisi ve koşulları, örgütün yapısı ve kültürü, mobbing yapılan kişinin koşulları; kişiliği, bir anlaşmazlık gibi tetikleyici bir neden ve toplumsal değer ve kurallar gibi etmenler psikolojik yıldırma davranışlarını doğuran temel nedenler olabilir.
İnsanların iş yerinde saldırganlığa başvurma sebepleri arasında (Okur, 2007:265);

- Örgütün güç kullanımı ve karar alma mekanizmalarında dengesizlik (Barutçugil,2004)

- Ekip dinamiklerindeki bozulmalar,

- Düşmanlıktan hoşlanmak,

- Saldırgan kişinin etrafında toplanan ekibin bu davranışı paylaşması,

- Önyargilar olmaktadır.

Psikolojik yıldırma davranışlarının kaynağ1 ne olursa olsun, çalışan üzerinde olumsuz sonuçlar yarattı̆̆ 1 kesindir. Çünkü psikolojik yıldırma mağduru çalışanın kişiliği yok sayılarak, duyguları bertaraf edilmektedir. Mağdur çalışan kendini savunmak yerine kurban rolünü kabullenmiş durumda kendini çaresiz hissetmekte, çözüm için bir çııış yolu bulamamaktadır.

\section{Psikolojik Yıldırma Davranışlarının Çalışan Üzerindeki Sonuçları}

İş yaşamında maruz kalınan psikolojik yıldırma davranışlarının bireysel ve örgütsel düzeyde birçok olumsuz etkisi olduğu bilinmektedir. Örgütsel anlamda, psikolojik yıldırmanın çalışanların iş tatmini, işten ayrılma ve örgütsel bağlılıklarını etkilediğ i çalışmalar ulusal ve uluslararası alanlarda yapılmaktadır. Örneğin, Karcıŏlu ve Çelik (2012:72)'in yapmış oldukları araştırmada, psikolojik yıldırma davranışlarının çalışanların örgüte olan bağlılıklarını ters yönde etkilediğ $i$ sonucuna varmışlardır. Karcıoğlu ve Akbaş'ın (2010:157) diğer bir çalışmasında elde edilen bulgularda ise, psikolojik yıldırmanın bir işyerinde yaşanması veya var olması durumunda iş tatmininin azalması veya iş tatminsizliğinin artacağ 1 gözlemlenmiştir. Psikolojik yıldırmanın örgütler için hem örgütün çalışanları hem de örgütün kendi sağlığını bozan önemli bir sorun olduğu sonucuna ulaşılmıştır. Yaman, Vidinlioğlu ve Çitemel (2010), on dört öğretmen üzerinde yaptıkları nitel bir araştırmada, psikolojik yıldırma davranışı gören öğretmenlerin işe gitmek istememe, huzursuzluk, depresyon ve 
bu durumu öğrencilere yansıtmak şeklinde olduğu sonuçlara maruz kaldığı sonucuna ulaşılmıştır. Ayrıca, psikolojik yıldırmaya mağruz kalan öğretmenlerin aile ve sosyal yaşamının olumsuz yönde etkilendiği sonucuna ulaşılmıştır. Kaymakçı (2008) ise psikolojik yıldırmanın çalışanların iş değiştirme düşüncesini, iş verimliliğini ve performansını etkilediği sonucuna ulaşmıştır.

Özellikle, çalışanların sosyal ve örgütsel yaşamına yansıyan psikolojik yıldırma yukarıda bahsi geçen araştırma sonuçlarının temelinde, psikolojik yıldırmanın çalışanların psikolojisinde yarattığı olumsuz sonuçlar yer aldığı düşünülmektedir. Çünkü psikolojik yıldırma davranışları çoğu zaman çalışan üzerinde kalıcı, psikolojik etkilere sahip olabilmektedir. Örneğin, Matthiesen ve Einersen, yaptıkları çalışmada uzun süre yıldırmaya maruz kalan bireylerin en çok anksiyeteye kapıldıklarını, belli olaylar ve durumlar karşısında aşırı tepki verdiklerini söylemektedir. Djurkovic, McCormack ve Casimic ise çalışmalarında yıldırma sonucunda çoğunlukla depresyon ve anksiyetenin birlikte görüldüğünü belirtmektedirler (Budak, 2008:395).

Davenport ve arkadaşlarına göre (Akt:Okur,2003:268) psikolojik yıldırma davranışının mağdur üzerinde üç etki derecesi bulunmaktadır.

Birinci Derece Mobbing: Kişi direnmeye çalışır, erken aşamalarda kaçar veya ya aynı iş yerinde ya da farklı bir yerde sorunun tamamen üstesinden gelir. Mağdurların bazıları karşı koymaya çalışırken bazıları anlayışla yaklaşabilir. İş ortamından duygusal olarak uzaklaşmaya ve başka bir iş aramaya başlar. Kişi işlevselliğini sürdürse bile şu belirtiler görülebilir. Ağlama, uyku problemleri, alınganlık ve konsantrasyon bozukluğu. $\mathrm{Bu}$ durum devam ederse ikinci derece mobbinge dönüşür.

İkinci Derece Mobbing: Kişi direnmez, kaçamaz, geçici veya uzun süren zihinsel veya fiziksel rahatsızlar yaşar ve geri dönmekte zorlanır. Uzun süre boyunca mobbinge maruz kalanlar da şu gibi belirtiler görülebilir. Yüksek tansiyon, kalıcı uyku bozuklukları, mide- bağırsak sorunları, konsantre bozuklukları, aşırı kilo verme veya alma, depresyon, işyerinden kaçma. $\mathrm{Bu}$ aşamada çalışanın yaşadı sorunlar sosyal çevresine yansımaktadır. Profesyonel yardım gerektiği sinyalleri alınmaktadır.

Üçüncü Derece Mobbing: Etkilenen kişi işine geri dönemez. Fiziksel veya psikolojik zarar görme ciddi boyutlardadır. Yalnızca çok özel bir tedavi uygulanmasının yararı olabilir. Üçüncü derece mobbing de insanlar iş yapamaz hale gelirler. İşe korku, dehşet ve nefret duyguları ile giderler. Bu aşamada şu belirtiler gözlenebilir. Depresyon, panik ataklar, kalp krizleri, ihtihar girişimleri, üçüncü kişilere yönelik şiddet, yapılan işlerde aksama, çalışanlar arasında iletişimde aksama ve güven kaybı, düşük verim, hastalık izin ve raporlarda artış, şirket aleyhine davaların açılmasıdır.

Psikolojik yıldırmaya maruz kalan çalışanlarda gözlemlenen stresle ilişkili semptomlar, psikolojik yıldırmaya maruz kalmayan çalışma arkadaşlarında gözlemlenen stres semptomlarına kıyasla çok daha yüksektir. İş çevresinin psikososyal yanının zayıf olması, yıldırma sürecinin ortaya çıkmasının ön koşullarından biridir. Ayrıca araştırmalardan elde edilen bulgular, psikolojik yıldırmaya maruz kalanların, çalışma ortamlarını maruz kalmamış bireylere kıyasla daha olumsuz algiladikları doğrultusundadır (Agedvold: Mikkelsen, 2004'den akt:Tinaz, 2006:105).

Psikolojik yıldırma, kişiler üzerinde stresi ve strese bağlı psikolojik ve fiziksel şikayetleri arttırmaktadır. Bu bağlamda, bu durumla karşı karşıya kalan bireylerde baş ağrısı, mide problemleri, kemik ağrıları, tansiyon yüksekliği, uyku problemleri, fiziksel şikayetler, konsantrasyon bozukluğu, endişe, bir faaliyete başlama güçlügü (atalet), sosyal izolasyon, ağlama nöbetleri, iştahta değişiklik gibi bulgulara rastlanmaktadır (Girardi,2007'den akt:Acar;Dündar, 2008).

2004-2005 yılları arasında Bosna Hersek'te psikolojik yıldırma ile stres arasındaki ilişkiyi inceleyen bir çalışmaya göre psikolojik 
yıldırmanın insanın sağlığına ve çalışma kabiliyetine olumsuz etkileri olduğu bulunmuştur. Psikolojik yıldırmanın strese yol açtığ ${ }_{1}$ ve stresin ise fiziksel rahatsızlıklar ortaya çıkardığı gözlemlenmiştir. $\mathrm{Bu}$ durum çalışanların ilaç kullanımını ve doktora başvurmalarını sıklaştırmıştır (Nurka,2007'den akt:Acar;Dündar,2008). Almanya ve İsveç'te yüzbinlerce psikolojik yıldırma mağdurunun erken emekli olduğu ve psikiyatri kliniklerinde yatarak tedavi oldukları belirlenmiştir (Tınaz, 2006:2).

Psikolojik yıldırmanın çalışan üzerindeki psikolojik etkisi oldukça ciddidir. Bu olumsuz etki çalışan bireyin sadece iş yaşamı ile sınırlı kalmamakta çalışan bireyin ailesi ve sosyal çevresi de etkilenmektedir. Aşırı stres, sürekli endişe durumu, depresyon hatta intihara kadar varan ruhsal karmaşalar yaşanmakta ve büyük bir toplumsal soruna dönüşebilmektedir.

\section{Endişe (Anksiyete) Nedir?}

Endişe stresle birebir ilişkili olan, tehlike veya talihsizlik korkusunun ya da beklentisinin yarattığı bunaltı veya tedirginlik olarak tanımlanabilir (Budak, 2003). Anksiyete, zamanda ve mekanda endişe odaklanmalarına denk düşen, az ya da çok belirgin sık krizlerle yaygin endişe durumudur (Gall,2006:55). Anksiyete durumundaki kişiler çoğu olaydan endişe hissi bir durumu yaratır. Stres endişe (anksiyete) oluşumunda çok önemli bir kaynağ1 teşkil eder.

Anksiyete keyifli bir insanı "kesinlikle kendisi olmak istememe, bir başkası olmak isteme" noktasına kadar götürür, endişeli insan kendini unutacak kadar kendinden geçmek ister. Gene aynı düzlemde, nispeten daha dengeli bir bilinç "kendisiyle ilgili olarak birşeyler düşünmek ister"; anksiyete, o zaman "umutsuzluk-zayıflık, pasif bir ben acısı" doğurur. Nihayet, başka bir düzlemde, "gerçekten kopma" düzleminde kaygıll insan umutsuzluğu yüzünden içine kapanır, konuşmaz ve bu noktada intihar riske ortaya çıkar(Gall,2006:50).

Anksiyete sonucu ortaya çıkan tepkiler genellikle benzerdir ancak kullanılan savunma düzeneklerine göre farklı belirtiler eşlik ederek farklı klinik tablolar oluşur. Genel anlamda kaygının dört belirti özelliği vardır bunlar (Merey, 2010); Bilişsel belirtiler: Gerçeklik duygusunda değişme, kontrolünü yitirme hissi, çldırma hissi, kötü bir haber alacağ 1 beklentisi, çevrenin değişiyor gibi algılanması, dikkat dağınıklığı, konsantrasyon güçlüğü, fiziksel zarar göreceği endişesi. Duygusal (affektif) belirtiler: Korku, huzursuzluk, endişe, tasa, sinirlilik, tahammülsüzlük, çaresizlik, alarm duygusu, panik. Davranışsal belirtiler: Kayg1 yaratan durumlardan kaçınma davranışı, dona kalma, çabuk irkilme, kolay yorulma. Fizyolojik belirtiler: Dolaşım sisteminde; çarpıntı veya kalp atım hızında artma, kan basıncı değişiklikleri, göğüste ağrı veya rahatsızlık hissi. Solunum sisteminde; nefes darlığı, hava açlığı, boğazda dügüumlenme, boğulma hissi. Yutma güçlügüu, bunaltı, kusma, ishal, karın ağrısı, sık idrara çıkma, cinsel isteksizlik. Cilt belirtileri olarak terleme, yüzde kızarma, sıcak veya soğuk basması, titreme, yerinde duramama veya gevşeyememe, uyuşma ya da ürperme hissidir.

\section{METODOLOJI}

Araştırma için, belirli bir evrendeki durumun ne olduğunun ve araştırılan karakteristiklerin ne kadar siklikta bulunduğunun belirlenmesine ve mevcut duruma anlam verilmesine yönelik durum saptayı1, betimleyici (Aziz, 1994:28) bir yöntem uygulanmıştır. Araştırma da, psikolojik yıldırmanın çalışanların "endişe " durumuna etkisi incelenmeye çalışılmıştır. Böylece psikolojik yıldırmanın çalışanların sağlığında oluşturduğu olumsuz sonuçların belirlenmesi amaçlanmıştır. Bu amaçla yola çıkılarak araştırma hipotezi aşağıdaki şekilde oluşturulmuştur.

H11: Psikolojik yıldırma ile çalışanların endişe durumu arasında anlamlı bir ilişki vardır.

$\mathrm{H1}_{2}$ : Psikolojik yıldırma ile çalışanların fiziksel endişe durumları arasında anlamlı bir ilişki vardir.

H13: Psikolojik yıldırma ile çalışanların bilişsel endişe durumları arasında anlamlı bir ilişki vardir. 
H14: Psikolojik yıldırma ile çalışanların davranışsal endişe durumları arasında anlamlı bir ilişki vardır.

H15: Psikolojik yıldırma ile çalışanların duygusal endişe durumları arasında anlamlı bir ilişki vardır.

Araştırmada veri toplama aracı olarak anket formu tercih edilmiş verilerinin analizi için SPSS 16.0 istatistik programı kullanılmıştır. Anket formunda, güvenirliliği ve geçerliliği kabul edilmiş ve birçok araştırmacı tarafından kullanılmakta olan iki ölçekten faydalanılmıştır. Bunlardan ilki Leymann "LIPT Questionnaire (Leymann Inventory of Psychological Terror)" tarafından geliştirilen "Psikolojik Terör Envanteri" dir; bu ölçekte 45 adet yıldırma davranışı verilmiştir. Anket sorularında 5'li Likert ölçeği kullanılmış (1-5) (Hiç katılmıyorum-Kesinlikle katılıyorum) şeklinde puanlandırılmıştır. Leymann psikolojik yıldırma davranışlarını beş boyutu ile ele almış ve çalışmada bu boyutlarıyla incelenmiştir. $\mathrm{Bu}$ boyutlar;

1. Kendini gösterme ve iletişime yönelik,

2. Sosyal ilişkilere yönelik,

3. İtibarına yönelik,

4. Yaşam kalitesi ve mesleki duruma yönelik,

5. Kişinin sağlığına yöneliktir.

Psikolojik yıldırma ölçeğinin geçerliliği ve güvenirliliği yapılan birçok araştırmada kabul edilmiştir. Ayrıca bu araştırmada ölçeğin güvenirliği hesaplamak için cronbach alpha güvenirlik analizi yapılmıştır. Ayrıca, ölçek maddeleri, item total korelasyonuna tabi tutulmuş ve negatif değere rastlanmamıştır. Ölçümler ortalamasındaki önemli farklılık olup olmadığına kontrol etmek için varyans analizi yapılmış ve önemli bir fark bulunmamıştır. Ölçeğin güvenirlik testi sonucunda ölçeğin alpha katsayıları; kendini gösterme ve iletişime yönelik boyut için $r=.81$, sosyal ilişkilere yönelik boyut için $r=.80$, itibarına yönelik boyut için $r$ $=.84$, yaşam kalitesi ve mesleki duruma yönelik boyut için $r=.88$ ve kişinin sağlığına yönelik $r$ $=.72$ olarak elde edilmiştir. Ölçeğin genel güvenirlik alpha katsayısı ise $r=92$ 'dir.
Araştırmada kullanılan ikinci ölçek "Dört Sistem Endişe Envanteri", Köksal ve Power (1987) tarafından ingilizce olarak, endişeyi(anksiyete) ölçmek için geliştirilmiş ve Türkçe'ye uyarlanması İnci Vural (1990) tarafından, 267 üniversite öğrencisi ve Marmara Üniversitesi Psikiyatri Kliniği'nde tedavi gören 75 anksiyete hastası ile yapılan çalışma sonucu oluşturulmuştur. Ölçekte kaygıyı; duygu, biliş, davranış ve somatik olmak üzere dört farklı boyutta ele alınmaktadır. 60 sorudan oluşan envanter "evet" ya da "hayır" şeklinde cevaplar kullanmaktadır. Her boyut 15 farklı soruyla ölçülmektedir (Merey, 2010).

Araştırma için "Dörtlü Sistem Endişe Envanteri" ölçeğin güvenirliği için yine SPSS 16.0 programinda güvenirlik analizleri yapılmıştır. Buna göre güvenirlik alpha katsayıları davranışsal boyut için $r=.70$, fiziksel boyut için $\mathrm{r}=.76$, bilişsel boyut için $\mathrm{r}=.68$, davranışsal boyut için $r=.82$ ve genel endişe envanteri açısından da $\mathrm{r}=.91$ olarak elde edilmiştir.

Anket formu; 4-7 Temmuz 2012 tarihleri arasında, bir Büyükşehir Belediye'sine bağlı ilçe belediye de 2'si geçici işçi $18^{\prime}$ i sözleşmeli olmak üzere 248 çalışan arasından 107 örnekleme üzerinde uygulanmıştır. Çalışmada evrenin tamamına ulaşılmaya çalışılmış 108 kişiye ancak ulaşılmıştır 1 anket ise eksiklik nedeniyle araştırmaya dahil edilmemiştir. Anket konunun hassasiyet göstermesi bakımından bizzat araştırmacılar tarafından gerekli açıklamalar yapılarak uygulanmiştır.

Araştırma verilerini değerlendirmek için frekans, ANOVA, t-testi ve psikolojik yildırma ve endişe arasındaki ilişki tespit etmek için basit korelasyon analizleri kullanılmıştır. Korelasyon ilişkisini belirlemek için, nicel değişkenler arasındaki ilişkinin belirlenmesinde kullanılan pearson korelasyon katsayısı esas alınmıştır.

\section{Bulgular}

Araştırmanın bu bölümünde katılımcilara ilişkin demografik bilgiler ve verilerin değerlendirilmesi bulunmaktadır. 
Tablo 1. Katılımcılara Ait Demografik Bilgiler

\begin{tabular}{|c|c|c|c|}
\hline & & $\mathbf{N}$ & FREKANS \\
\hline \multicolumn{4}{|l|}{ Cinsiyet } \\
\hline & Kadın & 45 & 42,1 \\
\hline & Erkek & 62 & 57,9 \\
\hline \multicolumn{4}{|l|}{ Yaş } \\
\hline & $18-24$ & 9 & 8,5 \\
\hline & $25-32$ & 33 & 30,8 \\
\hline & $33-41$ & 35 & 32,7 \\
\hline & 42 yaş ve üstü & 30 & 28 \\
\hline \multicolumn{4}{|l|}{ Eğitim } \\
\hline & İlköğretim & 18 & 16,8 \\
\hline & Lise ve dengi & 39 & 36,4 \\
\hline & Lisans & 46 & 44 \\
\hline & Lisansüstü & 4 & 3,7 \\
\hline \multicolumn{4}{|c|}{ Görev Süresi } \\
\hline & $0-5$ yıl & 18 & 16,8 \\
\hline & 6-12 yıl & 39 & 36,4 \\
\hline & $13-20$ yıl & 25 & 23,4 \\
\hline & 20 yıl ve üstü & 25 & 23,4 \\
\hline Toplam & & 107 & 100 \\
\hline
\end{tabular}

Tablo 1.'de katılımcıların demografik bilgileri görülmektedir. Tabloya göre katılımcıların \% 42,1'i kadın \% 57,9'u erkektir. $\mathrm{Bu}$ dağılım araştırma için uygun bir dağılım olduğu görülmektedir. Katılımcıların yaşları ise çoğunlukla 25-32 ve 33-41 yaş grubundan oluşmakta, eğitim düzeyleri ise çoğunlukla ilköğretim ile lise ve dengi okulu düzeyindedir. Katılımcların görev süreleri incelendiğinde ise çoğunluğu 6-12yıl ve üstü çalışma süresine sahiptir.

Tablo 2. 'de anket katılımciların demografik özellikleri ile dört boyutlu endişe durumlarında anlamlı farklılık olup olmadığını incelemek için elde edilen verilerin sonuçları yer almaktadır. Yaş, eğitim ve görev süresi ile dört boyutlu endişe durumu arasındaki anlamlı farklılık için ANOVA (Tek yönlü varyans) analizinden, cinsiyet için ise $\mathrm{t}$-Testi analizinden yararlanılmıştır.

Yapılan analizler sonucunda, anket katılımcıların görev süresi ile duygusal endişe boyutu arasında anlamlı farklılık bulunmuştur $(\mathrm{P}=0,022)$. Görev süresi ve duygusal endişe boyutu arasında bulunan anlamlı farklılı̆̆ın nedenini bulmak için yapilan post hoct ve sheffe testi sonucunda farklılığın 6-12 yil ve 1320 yıl arası çalışan katılımcilarda olduğu gözlenmiştir. Bu sonuca göre 6-12 yıl arası çalışan katılımcılar 13-20 yıl arası çalışan katılımclara göre daha duygusal endişeye sahip olduğu söylenebilir. 
Tablo 2. Katılımcıların Demografik Özellikleri ve Dört Boyutlu Endişe Durumunun Karşılaştırılmasına İlişkin ANOVA ve t-Testi Analizi

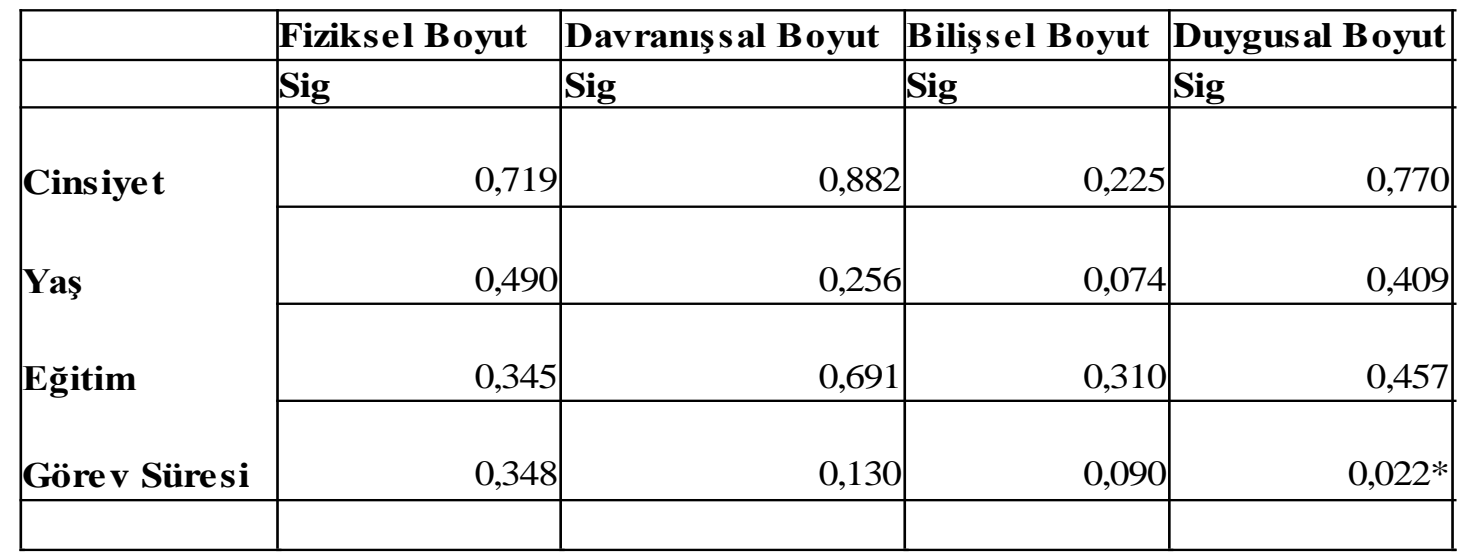

${ }^{*} \mathrm{p}<0,005$ Anlamlı Farklılık Vardır.

Tablo 3. Psikolojik Yıldırmanın Beş Boyutu ile Dörtlü Endişe Envanteri Arasındaki Korelasyon Analizi

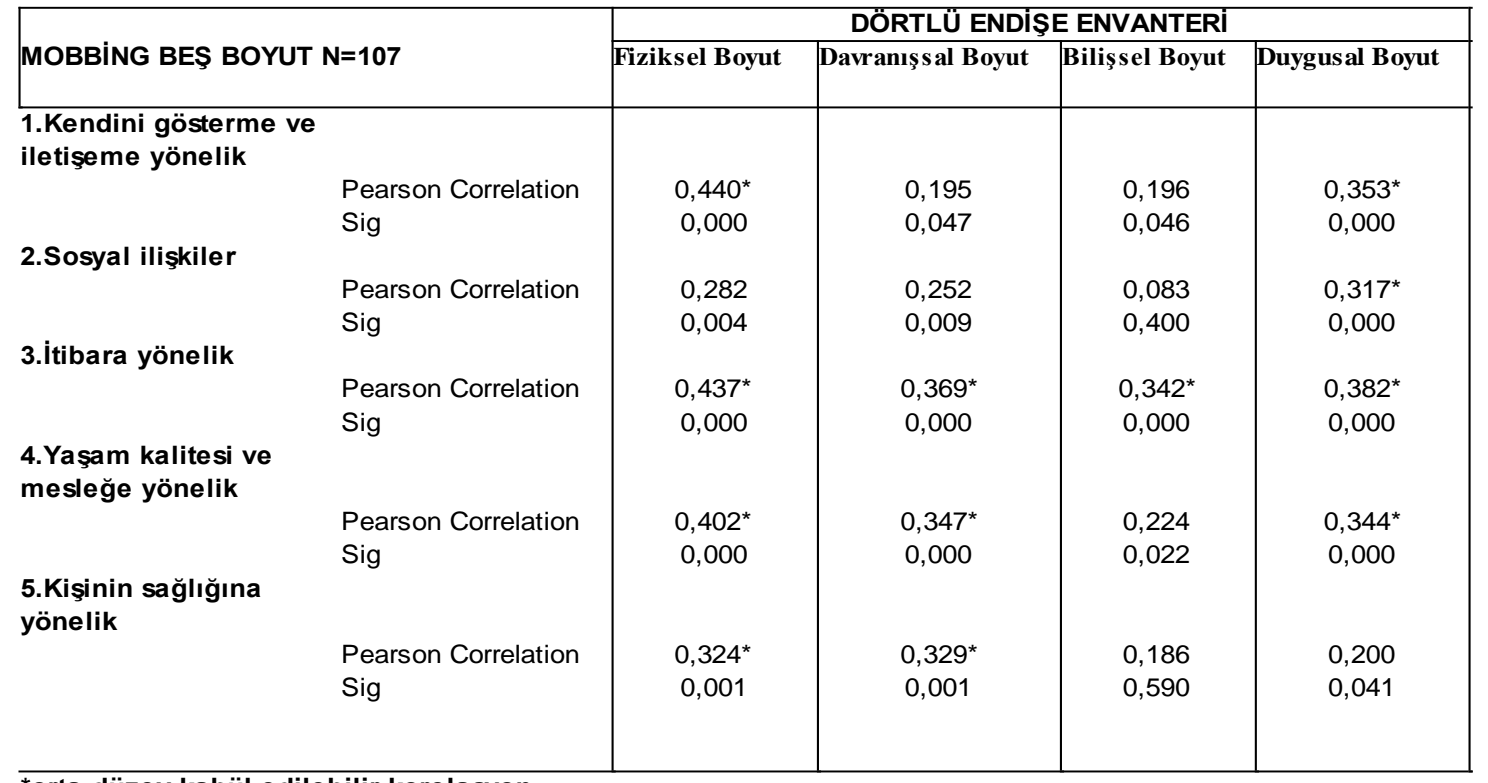

*orta düzey kabül edilebilir korelasyon

Tablo 3'te psikolojik yıldırmanın beş boyutlu davranışı ile dörtlü endişe envanterinin boyutları arasındaki korelasyon analizi görülmektedir. Yapılan analiz sonucu, psikolojik yıldırma davranışlarının "kendini gösterme ve iletişime yönelik" boyutu ile "fiziksel endişe" boyutu arasında ( $\mathrm{r}=$ $0,440, p \leq 0,005$ ) orta düzeyde pozitif yönde anlamlı bir ilişki bulunmuştur. Yine, "kendini gösterme ve iletişime yönelik" psikolojik yıldırma davranışı ile "duygusal endişe" boyutu arasında $(r=0,353, p \leq 0,005)$ orta düzeyde pozitif yönlü anlamlı bir ilişki saptanmıştır. Bu sonuç, $\mathrm{H}_{2}$ ve $\mathrm{H}_{5}$ hipotezlerini doğrulamaktadır.

"Sosyal ilişkilere yönelik" psikolojik yıldırma davranışı ile dörtlü endişe envanteri boyutları incelendiğinde, "sosyal ilişkilere yönelik" psikolojik yıldırma davranışı ile "duygusal endişe" boyutu arasında orta düzeyde $(\mathrm{r}=317, \mathrm{p} \leq 0,005)$ ve "fiziksel endişe" $(\mathrm{r}=0,282, \mathrm{p} \leq 0,005)$, "davranışsal endişe" $(\mathrm{r}=0,252, \mathrm{p} \leq 0,005)$ boyutları arasında düşük düzeyde pozitif yönde anlamlı bir ilişki 
bulunmuştur. $\mathrm{Bu}$ sonuç, $\mathrm{H}_{2}$ ve $\mathrm{H}_{4}$ hipotezlerini doğrulamaktadır.

"İtibara yönelik" psikolojik yıldırma davranışı ile "fiziksel endişe" $(\mathrm{r}=437, \mathrm{p} \leq 0,005)$, “davranışsal endişe" ( $r=369, p \leq 0,005)$, "duygusal endişe" $(\mathrm{r}=0,382, \mathrm{p} \leq 0,005)$ ve "bilişsel endişe" $(\mathrm{r}=0,342, \quad \mathrm{p} \leq 0,005)$ boyutları arasinda orta düzeyde pozitif yönlü anlamlı bir ilişki bulunmuştur. $\mathrm{Bu}$ sonuç, $\mathrm{H}_{2}, \mathrm{H}_{3}, \mathrm{H}_{4}$ ve $\mathrm{H}_{5}$ hipotezlerini doğrulamaktadır.

"Yaşam kalitesi ve mesleğe yönelik" psikolojik yıldırma davranışı ile "fiziksel endişe" $(\mathrm{r}=402, \mathrm{p} \leq 0,005)$, "davranışsal endişe" $(\mathrm{r}=347, \mathrm{p} \leq 0,005)$, "duygusal endişe" $(\mathrm{r}=0,344, \mathrm{p} \leq 0,05)$ boyutları arasında orta düzeyde pozitif yönlü anlamlı bir ilişki bulunmuştur. $\mathrm{Bu}$ sonuç, $\mathrm{H}_{2}, \mathrm{H}_{4}$ ve $\mathrm{H}_{5}$ hipotezlerini doğrulamaktadır.

\begin{abstract}
"Kişinin sağlığına yönelik" psikolojik yıldırma davranışı ile "fiziksel endişe" ( $r=324, p \leq 0,005)$, "davranışsal endişe" ( $r=329, p \leq 0,005)$, boyutları arasında orta düzeyde; ", "duygusal endişe" $(\mathrm{r}=0,200, \mathrm{p} \leq 0,005)$ çok zayıf düzeyde bir ilişki görülmektedir. $\mathrm{Bu}$ sonuç, $\mathrm{H}_{2}, \mathrm{H}_{4}$ ve $\mathrm{H}_{5}$ hipotezlerini doğrulamaktadır.

Tablo 4.'de psikolojik yıldırma davranışlarının beşli boyut üzerinde fiziksel endişeyi ne kadar açıkladığını anlamak için yapılan çoklu regrasyon analiz sonucunda, yıldırma davranışının fiziksel endişe durumunun \%28'ini açıkladığı görülmektedir. Psikolojik yıldırma davranışlarının alt boyutlarına bakıldığında bu etkinin en çok "kişinin sağlığına yönelik" yapıla yıldırma davranışının etkili olduğu görülmektedir $(B=0,256)$.
\end{abstract}

Tablo 4. Beş Boyutlu Psikolojik Davranışı ve Fiziksel Endişe Boyutu Çoklu Regresyon Analizi

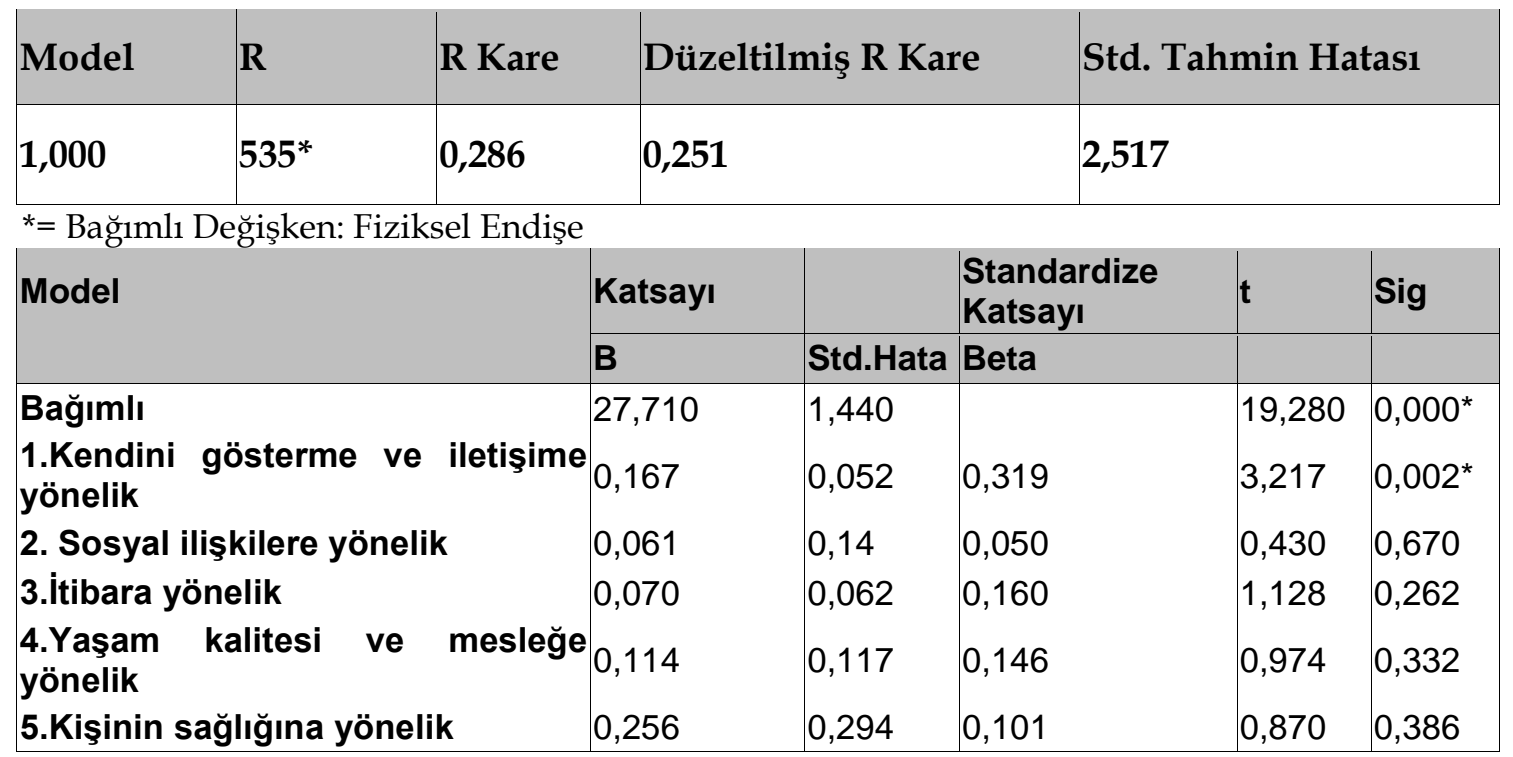

Bağımlı Değişken: Fiziksel Endişe ${ }^{*}=p<0,005$ anlamlı ilişki vardır.

Tablo 5.'de psikolojik yıldırma davranışlarının beşli boyut üzerinde “davranışsal endişenin" \% 16'sını açıkladığı görülmektedir. Psikolojik yıldırma davranışlarının alt boyutlarına bakıldığında bu etkinin en çok "kişinin sağllğına yönelik" yapılan yıldırma davranışının etkili olduğu görülmektedir $(\mathrm{B}=0,514)$.
Tablo 6.'da psikolojik yıldırma davranışlarının beşli boyut üzerinde "bilişsel endişenin" \%14'ünü açıkladığı görülmektedir $(R=0,142)$. Yıldırma davranışlarının alt boyutlarına bakıldığında bu etkinin en çok "sosyal ilişkilere yönelik" ve "itibara yönelik" yıldırma davranışlarının etkili olduğu görülmektedir $(B=0,357 ; 0,276)$. 
Tablo 5. Beş Boyutlu Psikolojik Yıldırma Davranışı ve Davranışsal Endişe Boyutu Çoklu Regresyon Analizi

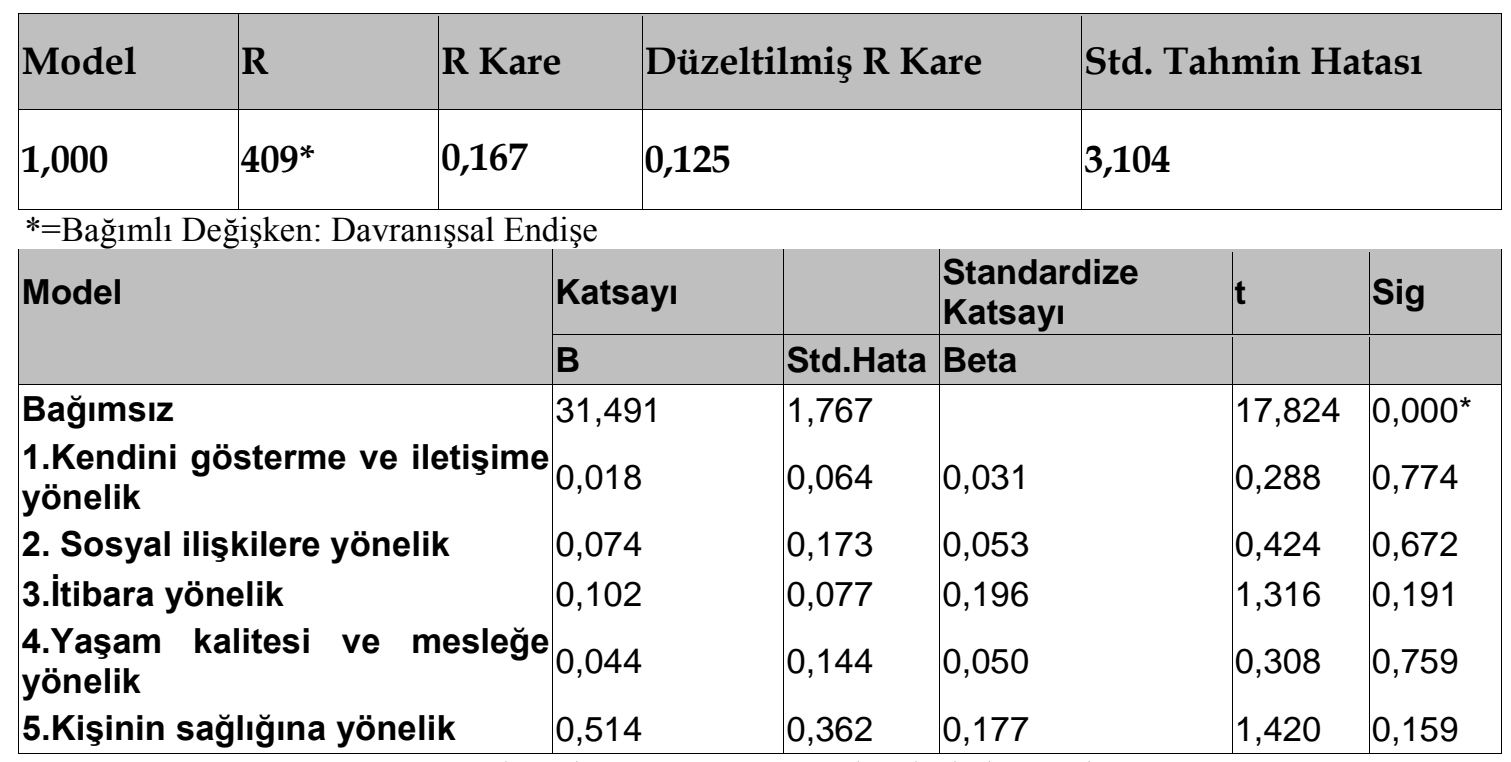

Bağımlı Değişken: Davranışsal Endişe * ${ }^{*} p<0,005$ anlamlı ilişki vardır.

Tablo 6. Beş Boyutlu Psikolojik Yıldırma Davranışı ve Bilişsel Endişe Boyutu Çoklu Regresyon Analizi

\begin{tabular}{|c|c|c|c|c|c|c|c|c|}
\hline Model & $\mathbf{R}$ & R Kare & \multicolumn{3}{|c|}{ Düzeltilmiş R Kare } & \multicolumn{3}{|c|}{ Std. Tahmin Hatası } \\
\hline 1,000 & $377^{*}$ & 0,142 & \multicolumn{2}{|l|}{0,098} & & \multicolumn{3}{|l|}{4,065} \\
\hline \multicolumn{9}{|c|}{ *=Bağımlı Değişken: Bilişsel Endişe } \\
\hline \multirow[t]{2}{*}{ Model } & & & Katsayı & & \multicolumn{2}{|c|}{$\begin{array}{l}\text { Standardize } \\
\text { Katsayı }\end{array}$} & t & Sig \\
\hline & & & B & Std.Hata & \multicolumn{2}{|l|}{ Beta } & & \\
\hline \multicolumn{2}{|c|}{ Bağımsız } & & 28,420 & 2,314 & \multirow{2}{*}{\multicolumn{2}{|c|}{0,073}} & 12,280 & $0,000^{*}$ \\
\hline $\begin{array}{l}\text { 1.Kendir } \\
\text { yönelik }\end{array}$ & gösterme ve & iletişime & 0,057 & 0,084 & & & 0,670 & 0,504 \\
\hline \multicolumn{3}{|c|}{ 2. Sosyal ilişkilere yönelik } & 0,357 & 0,227 & \multicolumn{2}{|l|}{0,199} & 1,574 & 0,119 \\
\hline \multicolumn{3}{|c|}{ 3.İtibara yönelik } & 0,276 & 0,101 & \multicolumn{2}{|l|}{0,413} & 1,316 & 0,191 \\
\hline $\begin{array}{l}\text { 4.Yaşam } \\
\text { yönelik }\end{array}$ & kalitesi ve & mesleğe & 0,023 & 0,188 & \multicolumn{2}{|l|}{0,020} & 2,717 & 0,008 \\
\hline \multicolumn{3}{|c|}{ 5.Kișinin sağlığına yönelik } & 0,027 & 0,474 & \multicolumn{2}{|l|}{0,007} & 0,057 & 0,954 \\
\hline
\end{tabular}

Bağımlı Değişken: Bilişsel Endişe $*=p<0,005$ anlamlı ilişki vardır. 
Tablo 7. Beş Boyutlu Psikolojik Yıldırma Davranışı ve Duygusal Endişe Boyutu Çoklu Regresyon Analizi

\begin{tabular}{|l|l|l|l|l|}
\hline Model & R & R Kare & Düzeltilmiş R Kare & Std. Tahmin Hatası \\
\hline 1,000 & $444^{*}$ & 0,197 & 0,157 & 3,295 \\
\hline
\end{tabular}

*= Bağımlı Değişken: Duygusal Endişe

\begin{tabular}{|c|c|c|c|c|c|}
\hline Model & $\begin{array}{l}\text { Katsayı } \\
\text { B }\end{array}$ & Std.Hata & $\begin{array}{l}\text { Standardize } \\
\text { Katsayı } \\
\text { Beta }\end{array}$ & $t$ & Sig \\
\hline Bağımsız & 30,596 & 1,876 & & 16,312 & $0,000^{*}$ \\
\hline $\begin{array}{l}\text { 1.Kendini gösterme ve iletişime } \\
\text { yönelik }\end{array}$ & 0,137 & 0,068 & 0,211 & 2,026 & 0,045 \\
\hline 2. Sosyal ilişkilere yönelik & 0,096 & 0,184 & 0,063 & 0,520 & 0,604 \\
\hline 3.İtibara yönelik & 0,088 & 0,082 & 0,157 & 1,074 & 0,285 \\
\hline $\begin{array}{l}\begin{array}{l}\text { 4.Yaşam kalitesi ve mesleğe } \\
\text { yönelik }\end{array} \\
\text { e }\end{array}$ & 0,136 & 0,152 & 0,141 & 0,889 & 0,376 \\
\hline 5.Kişinin sağlığına yönelik & 0,088 & 0,384 & 0,028 & 0,229 & 0,82 \\
\hline
\end{tabular}

Bağımlı Değişken: Duygusal Endişe ${ }^{*}=p<0,005$ anlamlı ilişki vardır.

Tablo 7.'de psikolojik yıldırma davranışlarının beşli boyut üzerinde "duygusal endişenin" \% 19'unu açıkladığı görülmektedir $(\mathrm{R}=0,197)$. Yıldırma davranışlarının alt boyutlarına bakıldığında bu etkinin en çok "yaşam kalitesi ve mesleğe yönelik" ve "kendini gösterme ve iletişime yönelik" yapılan yıldırma davranışının etkili olduğu görülmektedir $(\mathrm{B}=0,136 ; 0,137)$.

\section{TARTIŞMA}

Psikolojik yıldırma; üsttün asta veya astların birbirlerine yönelik olarak sergilediği organize ve süreklilik arz eden, mağdur üzerinde fiziksel veya psikolojik zarara yol açan, çok sık ve uzun bir dönem boyunca devam edebilen tacizci davranışlar ve saldırgan tutumlardır. Psikolojik yıldırma, iş yaşamının yapısını bozan, bireyler üzerinde karmaşık durumlar yaratan büyük bir stres kaynağıdır. Karmaşanın olduğu bu sağlıksız iş ortamlarda, sürekli ve belli aralıklarla yaşanan stresin bireyin psikolojik durumunda yıpratıcı sonuçlar doğurdu bu alanda yapılan bazı araştırma sonuçlarında görülmüştür. $\mathrm{Bu}$ araştırma da ise yıldırmaya maruz kalan çalışanların "endişe" durumu incelenmeye çalışılmış ve psikolojik yıldırma davranışları ile "endişe(anksiyete)" boyutları arasında anlamlı ilişki bulunmuştur.

Psikolojik bir rahatsızlık olarak "endişe" durumunda olan insanlar, iş ve sosyal yaşamlarını korku, kaygı duyguları ile devamlı aşırı bir stres altında geçirmektedir. $\mathrm{Bu}$ süregelen aşırı stres ve psikolojik travmalar bireyin sağlığını tehdit etmekte ve gerek iş yaşamında gerekse sosyal yaşamda büyük sıkıntılara yol açmaktadır. Özellikle iş yaşamında daha sık görülen psikolojik yıldırma davranışları, çalışanların "endişe" düzeylerinin artmasına yol açarak çalışanların psikolojik sağlıklarının olumsuz etkilenmesine, onların sosyal izolasyonuna ve iş performanslarının düşmesine sebep olmaktadır. Bu alanda yapılan bilimsel çalışmalarda bu durumu desteklemektedir. Örneğin; Hasalm ve diğerlerinin (2005) yaptığı bir araştırmada, işyerinde anksiyete ve depresyonun birey ve organizasyonlar üzerindeki etkisi incelenmeye çalışılmış, anksiyete ve depresyonun fiziki ve psikolojik belirtilerinin çalışanların iş performansını düşürdüğü ve iş kazaları riskini arttırdığ1 sonucuna ulaşılmıştır, Zapf ve diğerleri tarafından (1996) yapılmış başka bir araştırmada yine örgütsel faktörlerin psikolojik yıldırma davranışlarının potansiyel 
nedenlerden biri olduğu ve çalışanların psikolojik sağlıklarını olumsuz etkilediği sonucu elde edilmiştir.

"Endişe (anksiyete)" önemli bir psikolojik rahatsızlık olup, kişinin tüm yaşamını etkilemektedir ve yaşamını devamlı bir kaygı biçiminde geçirmesini sağlamaktadır, bu ruhsal bir çöküntüyü beraberinde getirmektedir.

Tüm bu olumsuz sonuçlar göz önüne alındığında işletmeler için psikolojik yıldırma davranışlarının kaynağının araştırılması, özellikle kişilik özelliklerinden kaynaklı olarak psikolojik yıldırma davranışı uygulayan bireylere karşı gerekli tedbirlerin alınması konusunda özen gösterilmelidir. İşletmenin organizasyonel yapısı psikolojik yıldırma davranışlarını engelleyici bir yapıda kurulmalı, çalışanların iş ve rol tanımları iyi yapılmalıdır. Ayrıca, çalışanların durumları dikkatle gözlemlenmeli, yaşanan bir psikolojik yıldırma davranışına erken müdahale edilmelidir. Bununla birlikte işletme içinde şikayet merci mekanizmalarının kurularak, bu mercilerin hızlı ve etkili bir şekilde çözüm üreten organizasyon yapısına dönüştürülmesi gerekmektedir.

Çalışana her daim örgüt içinde çözümün üretileceği güven verilmelidir. Çünkü, bireyin kaybettiği sağlığı geri kazanmanin hem sosyal hem de maddi maliyeti, tüm toplum açısından önemli bir kayıp olduğu unutulmamalıdır. Toplumdaki her birey beşeri ve fiziki kaynakların etkin ve verimli bir şekilde kullanılmasından birinci derecede sorumludur.

\section{SONUÇ}

$\mathrm{Bu}$ araştırmada, psikolojik yıldırma davranışlarının çalışanlar üzerindeki psikolojik etkisi literatür katkısıyla incelenmiş ve psikolojik yıldırma davranışları ile endişe durumu arasındaki ilişki gözlemlenmeye çalışılmıştır. Sonuç olarak, araştırmanın $\mathrm{H}_{1}$ hipotezi kabul edilmiş, psikolojik yıldırma davranışları ile (kendini gösterme ve iletişime yönelik, sosyal ilişkilere yönelik, itibara yönelik, yaşam kalitesi ve mesleğe yönelik, kişinin sağlığına yönelik), endişe (fiziksel, bilişsel, duygusal ve davranışsal) arasında anlamlı bir ilişki bulunmuştur. Özellikle bu anlamlılık çalışanların fiziksel endişe ve duygusal endişe durumlarında daha yüksek oranda görülmüştür (Bkz; Tablo 3).

$\mathrm{Bu}$ sonuçlara dayanılarak psikolojik yıldırma davranışına maruz kalan çalışanlarda psikolojik bir rahatsızlık olarak tanımlanan ve bireyin normal yaşantısını büyük oranda etkileyen "endişe (anksiyete)" durumuna rastlandığı söylemek mümkündür. Bu sonuç, $\mathrm{H} 1_{1}, \mathrm{H}_{2}, \mathrm{H}_{3}, \mathrm{H}_{4}$ ve $\mathrm{H}_{5}$ hipotezlerini doğrulamaktadır.

Araştırma sonuçları çalışma evreni ile sinırlıdır. Konunun hassasiyeti bakımından örneklem sayısı sınırlı kalmış olup, örneklem sayısının artması çalışma evrenini temsil etme bakımından önemli olacağı düşünülmektedir. Ayrıca, böyle bir araştırma; örneklem birim sayısı artırılarak genel evreni (çalışanlar) temsil etme olasılığ1 yüksek başka araştırmalar için ön bir çalışma niteliği taşımakta olup, psikolojik yıldırmanın çalışanlarda sebebiyet verdiği "endişe" durumunun incelemesi bakımından yazına katkı niteliği taşımaktadır. 
"iş, GÜç" Endüstri İlişkileri ve İnsan Kaynakları Dergisi

"IS, GUC" Industrial Relations and Human Resources Journal
Nisan/April 2013 - Cilt/Vol: 15 - Sayı/Num: 02

Sayfa/Page:63-81, DOI: 10.4026/1303-2860.2013.0226.x

\section{Kaynakça}

Acar, B. A., ve Dündar, G. (2008), İşyerinde Psikolojik Yildırmaya (mobbing) Maruz Kalma Sıklı̆̆ı ile Demografik Özellikler Arasındaki İlişkinin İncelenmesi, İstanbul Üniversitesi İşletme Fakültesi Dergisi, Cilt/Vol:37, Say1/No:2. elektronik erişim. (http://iudergi.com/tr/index.php/isletme/article/ viewFile/13842/13056http://iudergi.com/tr/inde x.php/isletme/article/viewFile/13842/13056http:/ /iudergi.com/tr/index.php/isletme/article/viewF ile/13842/13056

Avery, R., Bezmez, S., Edmonds G.A. ve Yaylalı M., (1999), Redhouse Sözlük, 29. Baskı, İstanbul: Sev Matbaacılık ve Yayıncılık

Aziz, A., (1994), Araştırma Yöntemleri-Teknikleri ve İletişim, Turhan Yayınları, Ankara.

Barutçugil, İ.,(2004), İnsanı ve Organizasyonu Anlamak; Organizasyonlarda Duygularm Yönetimi, s.13-43, İstanbul Kariyer Yayıncilık Edt:C.Başoğlu.

Beswick, J., (2006), Bullying At Work: A Review of The Literature,(Edit: Johanna Beswick, Joanne Gore, David Palferman), Buxton, Derbyshire: Harpur Hill.

Björkqvist; K., Österman, K. and Hjet_Back M. (1994), "Aggression Among University Employees", Aggressive Behavior 20: 173-184

Budak, S., (2003), Psikoloji Sözlüğü, Bilim ve Sanat Yayınları, Ankara.

Budak,G., (2008), Yetkinliğe Dayalı İnsan Kaynakları Yönetimi, Barış Yayınları Fakülteler Kitabevi, İzmir.

Çobanoğlu,Ş.,(2005), Mobbing İsyerinde Duygusal Saldırı ve Mücadele Yöntemleri, Timas Yayınları, İstanbul.

Davenport, Noa, Ruth D. Schwartz, Garl P.Elliot, (2003), Mobbing, İsyerinde Duygusal Taciz, Çeviren: Osman Cem Önertoy, Sistem Yayıncilık, İstanbul.
Einarsen S., (2000), "Harassment and Bullying at Work: A Review Of The Scandinavian Approach", and Violent Behavior, 5, 4, 379-401.

Hasalm, C., Atkinson, S., Brown, S.S., and Hasalm, R.A.(2005), Anxiety and depression in the workplace: Effect on the individual and organisation (a focus group investigation). Journa of Affective Disorders,88,209-215.

Gall Lee A., (2006), "Anksiyete ve Kaygı", Çeviren: İsmail Yerguz,Dost Kitabevi, Nisan, Birinci Baskı, Ankara

Leymann, H., (1996), "The Content and Development of Mobbing at Work", European Journal of Work and Organizational Psychology, 5 (2), 165 - 184.

Karcioğlu, F. ve Çelik, Ü.H.,(2012), Mobbing(Yıldırma) ve Örgütsel Bağhllı̆̆a Etkisi, Atatürk Üniversitesi, İktisadi ve İdari Bilimler Fakültesi Dergisi, Cilt.26 Sayı.1,59-75.

Karcioğlu, F. ve Akbaş, S.,(2010), İşyerinde Psikolojik Şiddet ve İş Tatmin İlişiksi, Atatürk Üniversitesi, İktisadi ve İdari Bilimler Fakültesi Dergisi, Cilt.24, Say1.3 139-161.

Kaymakçı, H.A. (2008), Çalışma Hayatında Mobbing (Sakarya imalat sektöründe bir araştırma), Yayımlanmamış Doktora Tezi, Sakarya: Sakarya Üniversitesi Sosyal Bilimler Enstitüsü

Merey,B.,(2010), Yetişkenlerde Özgüven Duygusu ile Anksiyete Düzeyi Arasındaki İlişkinin Karşılaştırılması ve Kültürlerarası Bir Yaklaşım, Maltepe Üniversitesi, Sosyal Bilimler Enstitüsü, Psikoloji Anabilim Dalı, Klinik Pskiloji, Yüksek Lisans Tezi, Ocak,İstanbul.

White, S., (2004), A Psychodynamic Perspective of Workplace Bullying: Çontainment, Boundaries End a Futile Search For Recognition,British Journal of Guidance\&Counselling,Vol.32,No.3, August, 268-280. 
Okur, B.C.,(2007), İşyerinde Duygusal Saldır (mobbing) ve Başa Çıkma Yöntemleri; Endüstriyel Klinik Psikoloji ve İnsan Kaynakları Yönetimi, Kurumdan Uygulamaya İş Yaşamında Psikoloji, Edt. Tarık Solmuş, Beta Yayınları.

Seigne,E.,(1998), "Bullying at work in Ireland", at Work Research Update Conference: Proceedings, Staffordshire University, Stafford.

Tayyar, S., (2008), İşletmelerde Psikolojik Yıldırma (Mobbing) ve Etkilerine Yönelik Bir Araștırma, Yüksek Lisans Tezi, Gebze Yüksek Teknoloji Enstitüsü Sosyal Bilimler Enstitüsü İşletme Anabilim Dalı

Tiyek, R.,(2011), Yıldırma ve Yönetim Becerileri Üzerine Bir Araştırma, Çalışma İlişkileri Dergisi,Cilt.2,Sayı,1

http://www.calismailiskileridergisi.org.

Erişim.15.11.2012

Tinaz, P.,(1996), İşyerinde Psikolojik Taciz (Mobbing), Beta basim, İstanbul.

Voroney, J. (2005), “Workplace Bulling: A Cultural Perspective",Culture Of Peace Online Journal 1(1): 23.

Yaman, E., Vidinlioğlu, Ö. ve Çitemel, N. (2010), İşyerinde Psikoşiddet, Motivasyon ve Huzur: Öğretmenler Çok Şey Mi Bekliyor? Psikoşiddet Mağduru Öğretmenler Üzerine. Uluslararası İnsan Bilimleri Dergisi7:1. Erişim:15.11.2012

http://www.insanbilimleri.com

Yıldız S., ve Kılkış İ., (2010), Psikolojik Taciz Olgusuna 4857 Sayılı İş Kanunu Açısından Bir Bakış, Çalışma İlişkileri Dergisi, Cilt.1 Sayı.1. http://www.calismailiskileridergisi.org.

Erișim.14.11.2012

Yücetürk, E.Elif (2005), “Örgütlerde Küresel Bir Yönetim Sorunu: Yildırma (Mobbing) ve Cinsiyetle İlişkisi", Çalışma Yaşamında Dönüşümler, Der.:Aşkın Keser, Nobel Yayın Dağıtım, Ankara.

Yücetürk, E.,Elif.: "Örgütlerde Durdurulamayan Yıldırma Uygulamaları: Düş Mü? Gerçek mi?", http://www.ikademi.com/orgutsosyolojisi/512-orgutlerde-durdurulamayan- yildirma-uygulamalari-dus-mu-gercek-miii.html. Erişim 15.10.2012

Zapf, D., (1999), “Organisational, Work Group Related and Personal Causes of Mobbing/Bullying at Work", International Journal of Manpower, $20,1 / 2$, ss. $70-85$

Zapf, D., Knorz, C., and Kulla, M. (1996), On the relationship between mobbing factor and job content. Social work environment and health outcomes. Europen Journal of Work and Organizational Psychology,5, 215-537.

\section{KAYNAKÇA}

AKTAY, Yasin (2008), "İslam Siyaset Felsefesinde Değer Algısı", Dem Dergi, Yıll2, Sayı: 5, s.8-15

AKYÜZ, Ünal (2009), "Siyaset ve Ahlak", Yasama, Sayı: 11, s. 93-129

ARAL, Halide (2008), “İçbütünlük Sorunu ve Modern Politik Ahlak", Çankaya Üniversitesi FenEdebiyat Fakültesi, Journal of Arts and Sciences, Sayı: 10, s. 11-17

BAYRAM, Ahmet Kemal, (2008), “Modern Zamanlarda Etik ve Siyasal Değerler". Dem Dergi, Y11:2, Sayı: 5, s.16-23

BOLAT, Tamer ve Aytemiz Seymen (2003), "Örgütlerde İş̧ Etiğinin Yerleştirilmesinde “Dönüşümcü Liderlik Tarzı"nın Etkileri Üzerine Bir Değerlendirme", Balıkesir Üniversitesi Sosyal Bilimler Enstitüsü Dergisi, Cilt: 6, Sayı: 9, s.59-85

BULUT, Nihat (2007), “Siyaset-Ahlak İlişkisi Bağlamında Siyasi Etik Komisyonu Kurulması Çalışmalarının Değerlendirilmesi", EÜHFD, C. XI, S. 3-4 s.1-28

ÇAM, Esat (2000), Siyaset Bilimine Giriș, Der Yayınları, İstanbul

DEMİR, Hulusi (1999), "Sosyal Sorumluluk ve İş Ahlakı", Balıkesir Üniversitesi Sosyal Bilimler Enstitüsü Dergisi, Cilt: 2, Sayı: 3, s.150-168

DURAK, İbrahim ve Atilla Yücel (2010), “Ahiliğin Sosyo-Ekonomik Etkileri ve Günümüze Yansımaları", Süleyman Demirel Üniversitesi 
İktisadi ve İdari Bilimler Fakültesi Dergisi, C. 15, Say1: 2, s.151-168

DURSUN, Davut (2005), “Siyaset ve Ahlak; Gerçeklikle İdealin Bağdaşmazlığ Sorunu", $2 .^{2}$ Siyasette ve Yönetimde Etik Sempozyumu, 18-19 Kasim 2005, Sakarya, http: //www.etiksempozyumu.sakarya.edu.tr/etik/1.1/durs un.pdf, Erişim Tarihi: 20.10.2012

ERTURHAN, Hilal ve Berrin Filizöz (2011), “İş Etiği ve Bankacılık Sektöründe Bir Araştırma”, C.Ü. İktisadi ve İdari Bilimler Dergisi, Cilt: 12, Sayı: 2, s.139-157

GÜNER, Semih (2002), "Avukatlık Meslek Etiği”, Ankara Barosu Dergisi, Sayı: 2, s.19-31

HÖKELEKLİ, Hayati (2008), “Güç İsteği, Siyaset ve Değer İlişkisi”, Dem Dergi, Yıl:2, Sayı: 5, s.24-29

İLHAN, Süleyman (2005), “İş Ahlakı: Kuramsal Bir Yaklaşım", Afyon Kocatepe Üniversitesi Sosyal Bilimler Dergisi, Y1l: 7, Sayı: 2, s.258-275

İŞGÜDEN, Burcu ve Adem Çabuk (2006), “Meslek Etiği ve Meslek Etiğinin Meslek Yaşamı Üzerindeki Etkileri", Balıkesir Üniversitesi Sosyal Bilimler Enstitüsü Dergisi", Cilt: 9, Sayı: 16, s.59-86

KAPANİ, Münci (1997), Politika Bilimine Giriş, 9. Baskı, Bilgi Yayınevi, Ankara

ÖZEN, Yener (2011), “Sorumluluk Bağlamında İş Ahlâkı Ve Sosyal Sorumluluk: Sosyal

Psikolojik Bir Yaklaşım”, Gümüşhane Üniversitesi Sosyal Bilimler Elektronik Dergisi, Sayı:4, s. 173-189

ÖZGENER, Şevki (2000), “Ekonomik Sistemler ve Ahlâk", Süleyman Demirel Üniversitesi İktisadi ve İdari Bilimler Fakültesi Dergisi, C. 5, S. 1, s.175-190

ÖZTEKİN, Ali (2001), Siyaset Bilimine Giriş, 3. Baskı, Siyasal Kitabevi, Ankara

POYRAZ, Hakan (), “Siyasi Ahlakın Coğrafi Sınırları: Ahlak Felsefesi ve Siyaset", Yerel Siyaset, s.16-20

SAKAL, Mustafa ve KİTAPÇI, İsmail (2009), “Siyasal Ahlak Dışı Davranışlara Farklı Bir Çözüm: Anayasal İktisat ve Ahlak Anlayışı", Sosyoekonomi, sayı: 2, s. $32-48$

SMITH, Katherine T. Ve L. Murphy Smith (2007), "İş ve Muhasebe Etiği", Çev.: İsmail Bekçi, Süleyman Demirel Üniversitesi İktisadi ve İdari Bilimler Fakültesi Dergisi, C. 12, S. 3, s.381-386

TORLAK, Ömer (2008), "Pazarlama ve Erdemlilik: Yanlış Algılar İçin Bir Açılım”, İş Ahlakı Dergisi, Cilt: 1, Sayı: 1, s.67-79
TÜRKÖNE, Mümtaz'er (2008), Siyaset, 8. Bask1, Lotus Yayınevi

TÜSİAD (2009), Dünyada ve Türkiye'de İş Etiği ve Etik Yönetimi,

http://www.tusiad.org/_rsc/shared/file/Tusiadisetigiraporupdf.pdf, E.T.12.12.20012

USTA, Aydın (2012), “Kamu Örgütlerinde Meslek Etiği ve Çalışma Ahlakı Üzerine Bir Değerlendirme", Süleyman Demirel Üniversitesi İktisadi ve İdari Bilimler Fakültesi Dergisi, C. 17, S. 1, s.403-421

YILDIRIM, Bilal (2005), “Eğitim Örgütlerinde Kültürel Liderlikle Meslek Ahlakı İlişkisi", Balıkesir Üniversitesi Sosyal Bilimler Enstitüsü Dergisi", C. 8, S.13, s.218-238

YOLDAŞ, Yunus (2007), “Max Weber'in (Siyasi) Sorumluluk Etiği Anlayışı", Süleyman Demirel Üniversitesi İktisadi ve İdari Bilimler Fakültesi Dergisi, C. 12, S. 2, s.199-218 